\title{
Affiliatieziekenhuizen: gelijkwaardige partner in het opleidingscontinuüm?
}

\author{
J.A.A.M. van Diemen-Steenvoorde, J.H. Hoekstra
}

\section{Samenvatting}

In dit artikel worden de consequenties besproken van het dreigende tekort aan artsen in onze maatschappij. In vele gremia is creatief gewerkt aan mogelijke oplossingen. Dit heeft geleid tot voorstellen voor essentiële wijzigingen in de curricula voor de basisopleiding en de specialistische vervolgopleidingen. Voor de basisopleiding is het implementatietraject al vergevorderd. In de praktijk blijkt dat deze veranderingen te samen met de uitbreiding van het aantal opleidingsplaatsen tot problemen heeft geleid in de algemene ziekenhuizen. Reeds nu is er een tekort aan docenten en ontbreekt er de infrastructuur in vele algemene ziekenhuizen om een optimaal onderwijsklimaat te realiseren.

De ontwikkeling van de academische onderwijs- en opleidingsregio (AOOR) lijkt een goede strategie om een netwerk te realiseren rond een UMC, waarin teaching hospitals naast stageziekenhuizen, een gezamenlijke verantwoordelijkheid dragen voor onderwijs en opleiding.

\section{Inleiding}

Vele maatschappelijke ontwikkelingen spelen een belangrijke rol in de vaststelling van het Capaciteitsorgaan dat een tekort aan artsen onafwendbaar lijkt. Het Capaciteitsorgaan heeft geadviseerd om op korte termijn een zeer omvangrijke uitbreiding van de opleidingscapaciteit te realiseren. Een uitbreiding van de instroom naar minimaal 2850 studenten in de basisopleiding is noodzakelijk: een uitbreiding met 1000 plaatsen ten opzichte van 1999. Daarnaast voorziet het Capaciteitsorgaan aanzienlijke tekorten voor vele specialismen als de opleidingscapaciteit niet wordt uitgebreid. Hiertoe heeft het Capaciteitsorgaan het Capaciteitsplan 2001 uitgebracht. ${ }^{1-2}$

Naast deze substantiële uitbreiding van het aantal op te leiden artsen is het noodzakelijk om de structuur van de opleidingen aan te passen. Met het project 'De arts van straks' is er een voorstel voor een nieuw medisch opleidingscontinuüm tot stand gekomen, waarin flexibel wordt ingespeeld op de maatschappelijke ontwikkelingen en de eisen die aan de arts van straks gesteld gaan worden. ${ }^{3-4}$ De afgelopen jaren hebben vele universiteiten al actief geanticipeerd op de ontwikkelingen in het veld door hun curriculum ingrijpend te wijzigen. De ontwikkeling van een bachelor-master structuur en de invoering van het zesde jaar als schakeljaar zouden de basis kunnen vormen om de initiële opleidingen geneeskunde en de medische vervolgopleidingen naadloos op elkaar aan te laten sluiten. In de vervolgopleidingen zal dit dan ook in onderwijskundig opzicht tot belangrijke veranderingen leiden. Het Centraal College Medische Specialismen (CCMS) besteedt veel aandacht aan de vernieuwing van de opzet en inrichting van de medisch specialistische opleidingen. Een betere koppeling van leerdoelen en leertrajecten, meer tijd voor 
reflectie op handelen en een sterke toename van modern modulair onderwijs in regionaal verband kunnen als voorbeelden worden genoemd. Dit vraagt om nieuwe voorzieningen en moderne informatietechnologie.

Over het algemeen bestaat er waardering voor de inhoud van deze veranderingen. Echter de praktische consequenties van het een en ander zijn aanzienlijk. Hoe voorkomt men dat de veranderingen in de praktijk niet haalbaar blijken te zijn? Waar en op welke wijze dienen al die dokters te worden opgeleid? Welke infrastructuur is noodzakelijk in de ziekenhuizen? Het is voor een ieder duidelijk dat er nog vele hobbels op de weg naar een succesvolle implementatie van het medisch opleidingscontinuüm overwonnen dienen te worden. Een intensieve samenwerking tussen universitaire medische centra (UMC's) en de algemene ziekenhuizen lijkt een conditio sine qua non, waarin uitgaande van de speerpunten en kwaliteiten van de partners, onderwijs en opleiding centraal staan.

\section{Organisatie}

In Nederland zijn er acht UMC's (samenwerkingsverbanden van de faculteit geneeskunde en het academisch ziekenhuis). Kerntaken van de UMC's zijn academische patiëntenzorg, wetenschappelijk onderzoek en onderwijs en opleidingen. Wat betreft de algemene ziekenhuizen hebben de grote topklinische ziekenhuizen een samenwerkingsverband (STZ) waarin onderwijs en opleiding belangrijk speerpunten zijn. De STZ ziekenhuizen hebben qua voorzieningen veel raakvlakken met enerzijds de academische ziekenhuizen en anderzijds de kleinere ziekenhuizen. Zij vormen de grootste algemene (niet universitaire) opleidingen. Bij de selectieprocedure voor nieuwe staf- leden is affiniteit met opleiden een belangrijk punt. Ruim 40\% van het totaal aantal co-schappen en een belangrijk deel van de specialistische vervolgopleidingen wordt in deze ziekenhuizen gevolgd. ${ }^{5} \mathrm{Op}$ korte termijn zullen die aantallen verder stijgen. Door de vele fusies van ziekenhuizen de afgelopen jaren ontstaat er in vele andere klinieken de mogelijkheid om opleiding en onderwijs verder te ontwikkelen. In recente aanbevelingen voor de organisatie van de medisch-specialistische zorg wordt dan ook gepleit voor meer congruentie tussen opleiding, onderzoek en patiëntenstromen. ${ }^{6}$

Om de uitbreiding van de opleidingscapaciteit te realiseren is een eerste vereiste dat de samenwerking tussen UMC's en de algemene ziekenhuizen wordt geoptimaliseerd. In een advies aan de ministers van OCenW en VWS wordt aangegeven dat een dergelijke samenwerking verbeterd kan worden door de introductie van een 'academische onderwijs- en opleidingsregio' (AOOR) rond elk UMC. ${ }^{7}$ Het streven is dat alle samenwerkingsrelaties in het kader van de co-schappen en de vervolgopleidingen binnen een AOOR gerealiseerd worden. In de praktijk betekent dit dat zich binnen de AOOR teaching hospitals, stageziekenhuizen, huisartsenpraktijken en andere extramurale werkplaatsen bevinden. In dit complexe veld moeten de academische ziekenhuizen een rol spelen in de regionale netwerkvorming. De UMC's hebben in die netwerken als kenniscentrum een innoverende taak. Binnen een AOOR dient sprake te zijn van een gezamenlijke beleidsvorming waarin van belang is om o.a. randvoorwaarden vast te stellen voor 'een goed opleidingsklimaat' en uitvoering van modulaire opleidingselementen. Vanuit de academische ziekenhuizen is men in 2002 van start gegaan met het uitwerken van het concept van de AOOR. ${ }^{8}$ 


\section{Innovatie}

Het is duidelijk dat de gewenste ontwikkeling veel consequenties heeft voor de algemene ziekenhuizen. Tekorten aan medische docenten (in aantal en in mensen met een brede blik), onvoldoende begeleiding en onvoldoende waardering voor dit werk (in tijd, in financieel opzicht en in carrièreperspectief) vormen een grote bedreiging voor deze tijdintensieve programma's. In de praktijk van alle dag is de druk van de patiëntenzorg vaak strijdig met de investeringen welke noodzakelijk zijn voor het onderwijs. Een oplossing voor deze structurele problemen lijkt de ontwikkeling van het concept 'teaching hospitals', naast (kleinere) stageziekenhuizen. Het begrip 'teaching hospital' wordt steeds vaker gebruikt binnen de ziekenhuissector. Tot nu toe zijn er echter geen uniforme criteria waaraan een ziekenhuis dient te voldoen om zich teaching hospital te noemen. In het algemeen praat men over een teaching hospital in dien er sprake is van een groot algemeen ziekenhuis met een omvangrijke, veelzijdige en kwalitatief goede patiëntenzorg, waaronder topklinische functies; een opleidingsziekenhuis dat een groot aantal co-assistenten een plaats kan bieden en dat erkend is om veel medisch specialistische opleidingen te verzorgen. De teaching hospitals hebben een strategische missie, welke primair is gelegen op het gebied van onderwijs(ontwikkeling) en opleiding. Het teaching hospital richt zich wat betreft de onderwijsfunctie op de medische, paraen perimedische en verpleegkundige beroeps- en vervolgopleidingen, waarbij klinische problematiek met een algemeen karakter centraal staat. Het beschikt over de benodigde infrastructuur voor onderwijs en opleiding. Naast enkele teaching hospitals zijn er binnen de AOOR vele stageziekenhuizen noodzakelijk om de vele studenten geneeskunde (delen van) hun co-schappen te kunnen laten lopen. Primaire taak van deze ziekenhuizen is het verrichten van patiëntenzorg, zij verlenen diensten op het gebied van onderwijs in een goed onderwijsklimaat.

De gewenste taakstellingen om in teaching hospitals grote groepen co-assistenten te kunnen accommoderen en assistenten op te leiden, vraagt om compensatie, zowel financieel naar opleiders en ziekenhuis, als ook naar de infrastructuur die ervoor nodig is. Het voorstel is om in deze ziekenhuizen alle onderwijs- en opleidingsactiviteiten, bijscholing en wetenschappelijke activiteiten samen te voegen in een aparte organisatie. Binnen deze dienst zijn geregeld de onderwijscoördinatie voor co-assistenten, opleidingscoördinatie van arts assistenten (introductie, arbeidsvoorwaarden, roosteren, trainingen, cursussen, evaluatie) en de onderwijscoördinatie van verpleegkundigen. Secretariële ondersteuning, voorzieningen (onderwijsruimten, bibliotheek, skillslab, informatietechnologie) en ondersteunende diensten (trainingen, cursussen, audiovisuele dienst) staan ten dienste van alle opleidingen in het teaching hospital. Ten aanzien van de bouwkundige voorzieningen zijn meerdere extra faciliteiten in teaching hospitals noodzakelijk (onderzoekkamers op afdelingen en poliklinieken, een skillslaboratorium, ruimte voor onderwijs in grotere groepen, studieposities in een goede bibliotheek en ICT faciliteiten). Op dit moment gelden voor de ruimtebehoeftenormering voor algemene ziekenhuizen onderwijsvoorzieningen als Pro Memorie (PM)-posten. ${ }^{9}$ Het is redelijk dat hier landelijk en binnen de AOOR gezamenlijke afspraken over worden gemaakt.

Naast een verandering van structuur dient ook de cultuur niet uit het oog te worden verloren. In een teaching hospital 
wordt opleiden een hoofddoelstelling. Zowel de opleiders als de organisaties zullen verantwoordelijk zijn voor een goede leerwerkomgeving. Een ieder dient zich binnen de organisatie bewust te worden van haar of zijn modelfunctie voor professioneel gedrag. ${ }^{10}$ Dit betekent in de praktijk dat in alle affiliatieziekenhuizen aandacht zal moeten worden besteed aan de didactische professionalisering. Het UMC binnen een AOOR zou dit kunnen faciliteren door gerichte docenttrainingen op locatie te verzorgen.

Deze nieuwe ontwikkelingen brengen extra kosten met zich mee voor de partnerziekenhuizen. In de nieuwe curricula, zo blijkt uit onderzoek, vraagt een co-assistent om vele uren begeleidingstijd. Dit onderwijs wordt deels door de specialisten en deels door arts-assistenten verzorgd. Dit heeft gevolgen voor de productie in de patiëntenzorg. Vakgroepen zullen hiervoor gecompenseerd moeten worden in formatie zodat het overige werk niet in het gedrang komt. De huidige affiliatievergoeding is ontoereikend om alle faciliteiten, een affiliatiecoördinator, het onderwijssecretariaat en co-assistentenopleiders te betalen. Recentelijk heeft de door de minister ingestelde Commissie Marktprikkels Medische Opleidingen geadviseerd de affiliatievergoeding fors uit te breiden. ${ }^{11}$ Binnen de regionale netwerken is voorzichtig een begin gemaakt om vanuit de UMC's, op basis van de gezamenlijke beleidsvisie, meer financiële ruimte te creëren voor de partnerziekenhuizen.

\section{Conclusie}

Het realiseren van de opleiding van 'de arts van straks' is een gemeenschappelijk belang. De UMC's en de partnerziekenhuizen stellen zich positief op om de praktische consequenties van het opleiden van meer artsen volgens moderne onderwijsconcepten in goed onderling overleg op te lossen. Het samenwerken binnen een AOOR kan een positief effect hebben op het implementatietraject. De ontwikkeling van teaching hospitals is een eerste vereiste voor het realiseren van extra opleidingsplaatsen binnen een nieuwe opleidingsstructuur. Daarnaast dienen vele kleinere stageziekenhuizen een rol te spelen in de uitbreiding van het aantal co-assistentenplaatsen. Een belangrijke financiële ondersteuning voor de partnerziekenhuizen is noodzakelijk voor het realiseren van de wenselijke structuur. Uitgaande van een gezamenlijke verantwoordelijkheid voor de zorg van nu en in de toekomst, zal het streven moeten zijn dat ieder ziekenhuis in ons land zijn aandeel in onderwijs en opleiden nauwkeurig gaat bepalen.

\section{Literatuur}

1. Leliefeld HJ, Holland PCHM. Toekomstig evenwicht. De nieuwste cijfers van het Capaciteitsorgaan. Medisch Contact 2002;57:660-2.

2. Velden LFJ van, Hingstman L, Nienoord-Buré CD, Berg MM van den. De vraag naar artsen becijferd. Een prognose van de opleidingscapaciteit 20002010. Medisch Contact 2001;56(12):446-51.

3. Crul BVM. Inspelen op de arts van straks. Betty Meyboom-de Jong over het medisch opleidingscontinuüm. Medisch Contact 2002;57:444-7.

4. Meyboom-de Jong B, Schmit Jongbloed LJ, Willemsen MC. De arts van straks. Een nieuw opleidingscontinuüm. Wijk bij Duurstede: Hentenaar; 2002.

5. Hoekstra JH. Een strategische missie. Topklinische ziekenhuizen worden teaching hospitals. Medisch Contact 2002;57:1645-7.

6. Medisch-specialistische zorg in de toekomst. Raad voor de volksgezondheid en sport; 2001.

7. Medische opleidingen: werk in uitvoering. Rapport van de VAZDMW-projectgroep gericht aan ministers van OC\&W en VWS. Vereniging Academische Ziekenhuizen; 2002.

8. Engel GL, Burema OJS, Blijham GH, GunningSchepers LJ. Meer en betere dokters. UMC's intensiveren klinische capaciteit. Medisch Contact 2002;57:1648-51. 
9. Rapport inzake overige p.m.-posten ruimtebehoeftenormering. Utrecht: College van Ziekenhuisvoorzieningen; 1996.

10. Bolhuis S. Professioneel leren: wat is het en hoe bevorderen we het? Tijdschrift voor Medisch Onderwijs 2002;21:173-82.

11. Commissie Marktprikkels Medische Opleidingen. Rapport: capaciteit en bekostiging en achtergronddocument. Ministerie Onderwijs, Cultuur en Wetenschappen; 2002.

\section{De auteurs:}

Mw. dr. J.A.A.M. van Diemen-Steenvoorde is kinderarts in het St. Antonius Ziekenhuis, Nieuwegein.

Dr. J.H. Hoekstra is kinderarts in het Jeroen Bosch Ziekenhuis, 's-Hertogenbosch.

\section{Correspondentieadres:}

Mw. dr. J.A.A.M. van Diemen-Steenvoorde, St. Antonius Ziekenhuis, Postbus 2500, 3430 EM Nieuwegein, tel: 030-6092071, fax: 030-6092602, ronnievandiemen@planet.nl.

\section{Summary}

In this article the consequences are discussed of an imminent shortage of physicians in The Netherlands. Many organisations are currently working on possible solutions. Medical schools are admitting more students. At the same time fundamental curriculum changes for medical schools and resident programs are proposed. These changes imply a greater time demand on clinical staff. In practice the expanding number of residencies have led to a greater orientation for teaching in large general hospitals. However, only recently this has become a primary orientation for many of these hospitals. In addition, many of these institutions lack a proper infrastructure to realise an optimal educational climate.

The development of a combined program for education and training around every academic hospital could be a good strategy to realise a network of hospitals with joint responsibilities for education and training. 